\title{
Effect of Punicalagin on maternal live body weight during pregnancy in virgin
}

\section{rabbit does}

\author{
Anas A. Salem ${ }^{1}$, M. Kobeisy ${ }^{1}$, Hoda M. Shabaan ${ }^{2}$, Nada A. El-Shahawy ${ }^{2}$ \\ ${ }^{1}$ Animal Production Department, Faculty of Agricultural, Assiut University, Egypt \\ ${ }^{2}$ Institute of Animal Production Research, Dokki, Giza, Egypt \\ doi:
}

\section{AbSTRACT}

Reactive oxygen species (ROS) is collective term both oxygen radical, such superoxide $\left(\mathrm{O}_{2} \cdot\right)$, hydroxyl $(\mathrm{OH} \bullet)$, peroxyal $\left(\mathrm{RO}_{2} \bullet\right)$, and hydroperoxyl $\left(\mathrm{HO}_{2} \bullet\right)$, and certain non-radical oxidizing agents, such as hydrogen peroxide $\left(\mathrm{H}_{2} \mathrm{O}_{2}\right)$, hypochlorous acid (HOCL), and ozone (O3), that can be convert easily to radical. The importance of antioxidants is shown here punicalagin. Punicalagin prevents harmful effect of (ROS) in all cell especially gonadal cells. So, the aim of study was to investigate effects of punicalagin (PL) on maternal live body weight (MLBW) during pregnancy in virgin rabbit does. In normal state, the decline in levels of free radicals is coupled with increased antioxidant and the reverse is true, but there is a critical balance between them during the development. Also, redox signaling induced by environmental pollutants (stressors) involve both alterations in antioxidant defenses and accumulation of ROS leading to oxidativestress which acts as a critical pathophysiological mechanism. This disturbance has deleterious effect on female reproductive.ROS due to environmental pollutants may result with high risk of any type of diseases producing developmental delay. Thus, maintaining the balance between antioxidants and ROS during pregnancy or lactation period may play an important role in maternal live body weight.

\section{KEYWORDS}

Antioxidants,

Punicalagin, Reactive

Oxygen Species,

Maternal live body

weight.

\section{CORRESPONDING} AUTHOR

Nada A. El-Shahawy

n_a_d_a_66@windowslive.com

\section{INTRODUCTION}

Today, there is a special attention toward the use of antioxidants extracted from some plants in various pharmacological purposes, for instance, pomegranate ( $P$. granatum) has been shown to have various medicinal values such as antioxidant, antimicrobial, anti-diabetic, cardio-protective and anti-carcinogenic activity (Morton 1987; Longtin 2003; Ajaikumar et al., 2005; Adhami and Mukhtar 2007; Rahimi et al., 2012). Punica granatum is the scientific name of pomegranate fruit, it is known as a paradise fruit in the Islamic religion. Pomegranate is cultivated in many different regions of Egypt especially in Upper-Egypt. It grows in hot arid regions (Sarkhosh et al., 2007). Pomegranate contains different bioactive compounds such as vitamins B2, C, and B1, and folic acid, pantothenic acid, sugars, organic acids, alkaloids, polyphenols, and anthocyanins as evidenced by reports of (Hussen 2014).They indicated also that using pomegranate extract reduced the hormonal complications of polycystic ovary syndrome of female Wistar rats. Hydrolyzed tannins known as punicalagins constitute the most important polyphenols of pomegranate juice (Poyrazoglu et al. 2002), this juice of red color is due to presence of anthocyanins such as delphinidin, cyanidin, and pelargonidin glucoside (Poyrazoglu et al. 2002), this juice of red color is due to presence of anthocyanins such as delphinidin, cyanidin, and pelargonidin glucoside (Khoo et al. 2017). Additionally, pomegranate seed oil is considered as one of the six known sources of saturated and 
unsaturated fatty acids as evidenced by reports of (Hernández et al. 2011). Meanwhile, pomegranate is an antioxidant-rich fruit contained a large amount of vitamin $\mathrm{C}$ and potassium, Amini Rad et al. (2009).Little is known about effects of $\mathrm{P}$. granatum on maternal live body weight during pregnancy in virgin rabbit does in gestate at first time, where, young rabbits need much care during the first pregnancy to avoid early embryonic mortality, meanwhile not all follicles found in the ovary during the estrous cycle reach their final stage of development and hence the ovulation.

\section{EXPERIMENT DESIGN}

The experiment was carried out in the period from March to July, 2018 in the experimental unit linked to the Poultry Production Farm, Faculty of Agriculture, Assiut University, Assiut (Upper Egypt). The aim of study was to investigate effects of punicalagin (PL) on Maternal live body weight (MLBW).

\section{Animals}

A total of 14 health WNZ rabbit does (6 months of age with mean live body weight $3.15 \pm$ $0.21 \mathrm{~kg}$ were divided into 2 randomly equal groups. Group I, each doe was injected IM with $100 \mu \mathrm{g}$ PL (according to Packova et al. (2015)/animal (Sigma, P00023-10MG punicalagin from pomegranate CAS: 65995-63-3, Sigma-Aldrich) 3 times (2 times a week pre-mating and one time 3 days postmating). Group II, each doe was injected IM with sterilized water and considered as control. Before starting the experiment animals were vaccinated with Formalized Polyvalent Rabbit Pasteurellosis Vaccine (Vet. Ser. and Vac. Res. Inst. Cairo, Egypt) against bacterial septicemia and viral haemorrhgeic diseases. All does were weighed by using a digital balance in the intervals mentioned above at $1^{\text {st }}$ and $2^{\text {nd }}$ pregnancy. All animals received superior care during the experiment and the contaminations that affect welfare of animals were avoided during the study.

\section{Feeding}

All rabbit does were fed a ration contained $18.25 \%$ crude protein, $2.29 \%, 13.40 \%$ crude fiber and crude fat $(2700 \mathrm{Kcal} / \mathrm{Kg}$ ration ME according to NRC-(1977). Ingredient constituents of the pelleted diet were yellow corn, soybean meal (44\%), wheat bran, alfalfa hay, di-calcium phosphate, limestone, sodium chloride, antitoxins, methionine, lysine and dry yeast. Each doe was fed ad libitum on this commercial diet throughout the experiment. Water was available through the automatic drinkers attached in the galvanized wire cages.

\section{Housing}

All animals were individually housed in galvanized wire batteries $(60 \times 50 \times 35 \mathrm{~cm})$ located in 3 naturally ventilated and lighted (13 h light: $11 \mathrm{~h}$ dark) rooms, the dimensions of each room are $5.3 \mathrm{x}$ $3.6 \times 2.8 \mathrm{~m}$. The average ambient temperature degrees and relative humidity percentages inside the rooms were ranged of $26.01-31.21{ }^{\circ} \mathrm{C}$ and 36.29 $48.59 \%$. Near kindling by 5 days, wooden nest boxes (contained straw or hay besides fur pulled from mother with dimensions $40 \mathrm{~cm}$ (length) x 26 $\mathrm{cm}$ (width) $\times 27 \mathrm{~cm}$ (height) were attached to the dam's cages. The bedding was replaced daily by new one to avoid any contamination from the urine or fecal material. Further nipples of mother were examined to know if the mother is lactating, then return her to her kits immediately. Weight was done by taking the kits out of nest box, then, the boxes were removed at weaning period (4 weeks). From birth to weaning all kits were left to their dams to nourish milk with no any treatments. All does used at $1^{\text {st }}$ pregnancy were naturally re-mated after 10 days of the first kindling with no any additional treatments. This part was conducted to confirm the results of treatments obtained from the first pregnancy on the $2^{\text {nd }}$ pregnancy outcomes.

\section{Mating}

Does were naturally mated by fertile bucks having high quality of semen characteristics, physical conformation and vigor. Each buck was mated to equal number of control and treated does. After 10 days of the first kindling the does were naturally mated by the same bucks used at mating in the $1^{\text {st }}$ pregnancy. Conception rate was determined 
by palpation after 10 days of mating in both $1^{\text {st }}$ and $2^{\text {nd }}$ pregnancy.

\section{Statistical analysis}

Data entry and analysis were done using SPSS version 19 (Statistical Package for Social Science). Data were presented as mean and standard error. Mann-Whitney test was used to compare quantitative variables between two groups. P-value was considered statistically significant when $\mathrm{P}<$ 0.05 .

\section{RESULTS AND DISCUSSION}

At mating in the $1^{\text {st }}$ and $2^{\text {nd }}$ pregnancy, MLBW was $(\mathrm{P}<0.05)$ greater in $\mathrm{PL}$ than the controls. At 3 days post-mating in the 2nd pregnancy, MLBW was $(\mathrm{P}<0.05)$ greater in $\mathrm{PL}$ than the controls. In the last three weeks of pregnancy and post-kindling in the two pregnancies, MLBW was $(\mathrm{P}<0.05)$ greater in PL than the controls (Table 1). This means that PL achieved increase in MLBW during mating and pregnancy. Moreover, PL achieved weight gain $(+0.49 \mathrm{~kg})$ in the 1 st pregnancy and $+0.19 \mathrm{~kg}$ in the 2nd pregnancy) as compared with the controls (Fig. 1). Protecting proteins in the tissues from ROS damages is of importance in maintaining body heath. In the current results PL achieved increase in MLBW at mating and pregnancy, there are two ways for illustration of that increase 1) this may due to the potent polyphenols of PL which are important in protecting the lipids and amino acids from ROS damages as reported by Kulkarni et al. (2007) or may due to the increase in the fetal growth, where the KWs in the present study were greater at birth and weaning, this illustration is in consistent with findings of Vazquez-Gomez et al. (2017) who reported that piglets produced from the treated dams with hydroxytyrosol (a polyphenol present in olive) improved pre-and-post-natal development of offspring and had mean birth weight more than the control.

Table (1) Mean \pm SE of MLBW throughout the different periods of the first two pregnancies of young NZW rabbit does.

\begin{tabular}{|c|c|c|c|c|}
\hline Periods & Pregnancy & $\mathrm{PL}$ & Control & P-Value \\
\hline pre-mating & \multirow{7}{*}{ I } & $2.80 \pm 0.48$ & $3.36 \pm 0.10$ & 0.370 \\
\hline $1^{\text {st }}$ mating & & $3.19 \pm 0.08$ & $2.95 \pm 0.06$ & $0.025^{*}$ \\
\hline 3 days post-mating & & $3.29 \pm 0.09$ & $3.10 \pm 0.04$ & 0.096 \\
\hline $1^{\text {st }}$ week & & $3.60 \pm 0.09$ & $3.18 \pm 0.05$ & $0.004 *$ \\
\hline $2^{\text {nd }}$ week & & $3.75 \pm 0.08$ & $3.29 \pm 0.05$ & $0.003^{*}$ \\
\hline $3^{\text {rd }}$ week & & $3.85 \pm 0.10$ & $3.39 \pm 0.05$ & $0.002 *$ \\
\hline $1^{\text {st }}$ kindling & & $3.29 \pm 0.11$ & $2.99 \pm 0.01$ & $0.004 *$ \\
\hline $2^{\text {nd }}$ mating & \multirow{6}{*}{ II } & $3.88 \pm 0.11$ & $3.38 \pm 0.06$ & $0.007 *$ \\
\hline 3 days post-mating & & $3.90 \pm 0.11$ & $3.45 \pm 0.08$ & $0.010^{*}$ \\
\hline $1^{\text {st }}$ week & & $3.77 \pm 0.10$ & $3.36 \pm 0.06$ & $0.015^{*}$ \\
\hline $2^{\text {nd }}$ week & & $3.75 \pm 0.12$ & $3.32 \pm 0.07$ & $0.022 *$ \\
\hline $3^{\text {rd }}$ week & & $3.67 \pm 0.10$ & $3.10 \pm 0.06$ & $0.007^{*}$ \\
\hline $2^{\text {nd }}$ kindling & & $3.30 \pm 0.11$ & $2.80 \pm 0.04$ & $0.004 *$ \\
\hline
\end{tabular}

*Significance at 0.05 . 


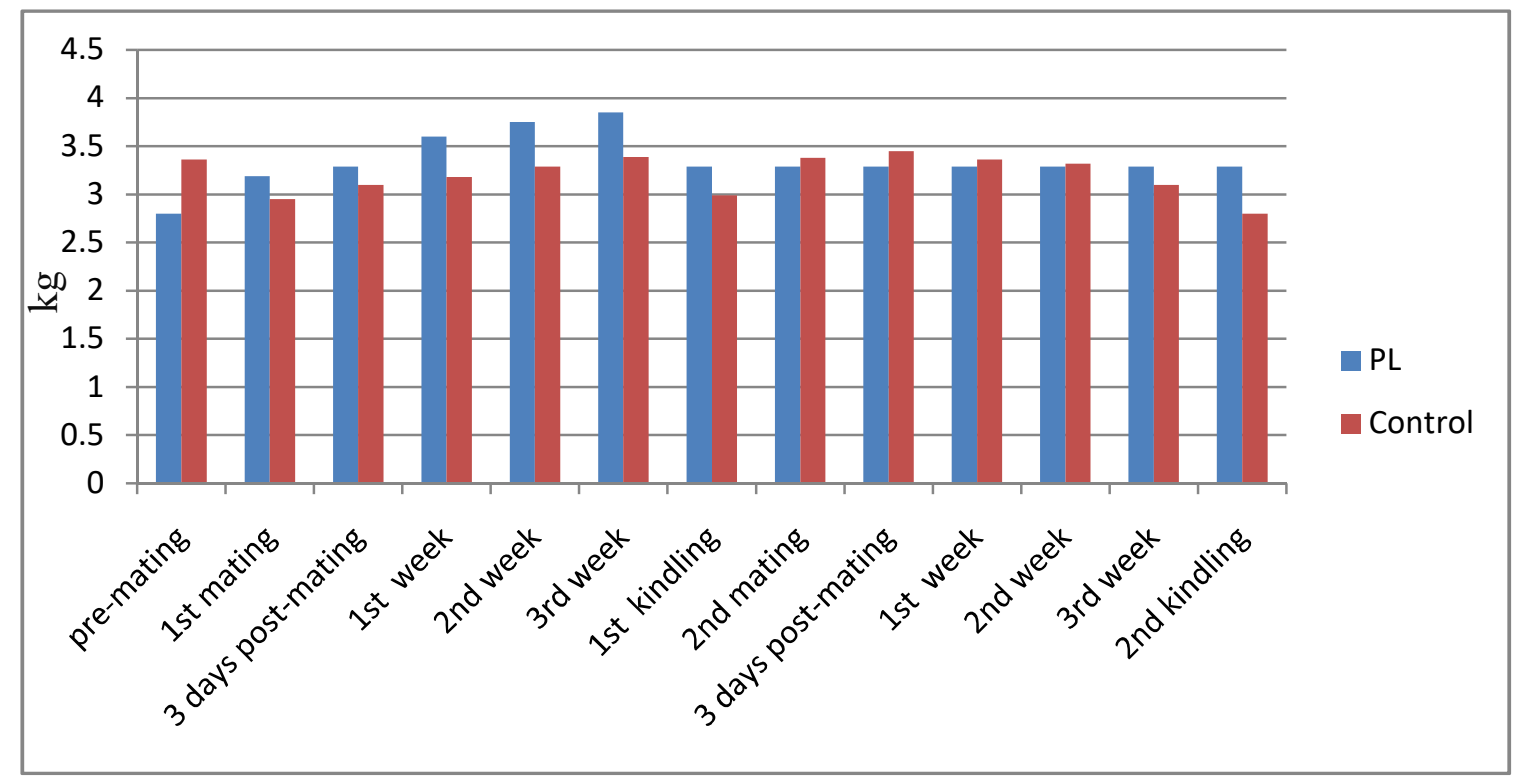

Figure (1) MLBW throughout the different periods of the first two pregnancies of young NZW rabbit does.

\section{REFERENCES}

Adhami V. M. and Mukhtar H., (2007). Antioxidants from green tea and pomegranate for chemoprevention of prostate cancer. Mol. Biotechnol., 37: 52-57.

Ajaikumar K.B., Asheef M., Babu B.H. and Padikkala J., (2005). The inhibition of gastric mucosal injury by Punica granatum L. (pomegranate) methanolic extract. J. Ethnopharmacol., 96: 171-176.

Amini Rad O., Khalili M.A. and Soltani Gord Faramarzi H.R., (2009). Influence of pomegranate juice on sperm parameters and fertility in mice (Article in Persian). Medical Journal of Hormozgan University, 13: $182-188$.

Hernández F., Melgarejo P., Martínez J.J., Martínez R. and Legua P., (2011). Fatty acid composition of six oils from important Spanish pomegranate cultivar. In: Ital. J. Food Sci., 23: 188-193.

Hussen, W. M., (2014). Protective Role of Pomegranate Peel Extract on Testis in Adult Male Rabbits Treated with Carbon Tetrachloride. The Iraqi Journal of Veterinary Medicine, 1:74-82.
Khoo H. E., Azlan A., Tang S. T., and Lim S. M., (2017). Anthocyanidins and anthocyanins: colored pigments as food, pharmaceutical ingredients, and the potential health benefits. Food \& Nutrition Research, 1:136-177.

Kulkarni A.P., Mahal H.S., Kapoor S. and Aradhya S.M., (2007). In vitro studies on the binding, antioxidant and cytotoxic actions of punicalagin. J. Agric. Food Chem., 55:1491-1500.

Longtin R., (2003). The pomegranate: nature's power fruit? J Natl Cancer Inst., 95:346-348.

Morton J., (1987). Pomegranate. In: Fruits of Warm Climates, Morton, J.F. (Ed.). Florida Flair Books, Miami, pp: 352-355.

N.R.C., (1977). Nutrient Requirements of Rabbits. National Research Council, Washington DC.

Poyrazoglu E., Goekmen V.and Artik N., (2002). Organic acids and phenolic compounds in pomegranate (Punica granatum L.) grown in Turkey. Journal of Food Composition and Analysis, 15: 567-575. 
Rahimi H.R., Arastoo M. and Ostad S.N., (2012). A comprehensive review of Punica granatum (Pomegranate) properties in toxicological, pharmacological, cellular and molecular biology researches. Iran. J. Pharm. Res., 11: 385-400.

Sarkhosh A., Zamani Z., Fatahi R., Ghorbani H. and Hadian J., (2007). A review on medicinal characteristics of pomegranate (Punica granatum L.). J. Med. Plants, 22: 13-24.
Vazquez-Gomez M., Garcia-Contreras C., Torres-Rovira L., Pesantez J. L., Gonzalez-Añover P., Gomez-Fidalgo E., Sanchez-Sanchez R., Ovilo C., Isabel B., Astiz S. and Gonzalez-Bulnes A., (2017). Polyphenols and IUGR pregnancies: Maternal hydroxytyrosol supplementation improves prenatal and early-postnatal growth and metabolism of the offspring. PLoS One, 12(5): e0177593.

\section{الملخص العربى}

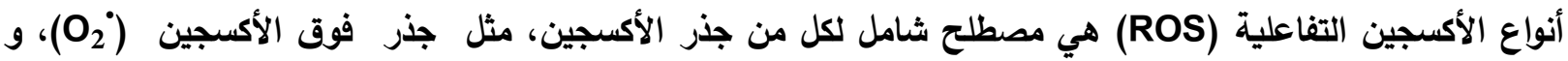

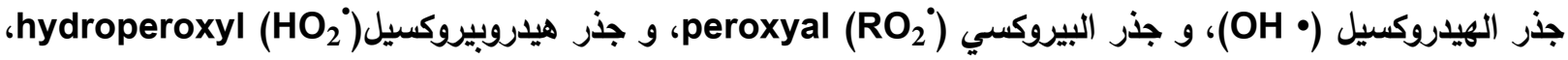
وبعض عوامل الأكسدة غير الجذرية، مثل الهيدروجين بيروكسيد (HOCL) (HOCL)، والأوزون (الم)، والتي يمكن تحويلها بسهولة إلى جذري. وتظهر أهمية مضادات الأكسدة هنا البونيكالاجين. البونيكالاجين يقوم بمنع التأثير الضار لـ (ROS) للجذور الحرة (أنواع الأكسجين التفاعلية) في جميع الخلايا وخاصة خلايا الغدد التناسلية. لذا، كان الهاف من الاراسة هو التحقيق في آثار البونيكالاجين على وزن الجسم الحي للأمهات فى المراحل المختلفة من الحمل فى الأرانب البكر. في الحالة الطبيعية، يقترن انخفاض مستويات الجذور الحرة بزيادة مضادات الأكسدة والعكس صحيح ، ولكن هناك توازن حرج بينهما خلال مراحل التطور المختلفة ـ أيضا ، هناك إثارات للأكسدة يسبيها الملوثات البيئية (الضغوطات) تتضمن على كل من التعديلات في دفاعات المضادة للأكسدة وتراكم للجذور الحرة مما يؤدي إلى الإجهاد التأكسدي الأي يعمل كآلية فيزيولوجية مرضية حرجة. و هذا الاضطراب له تأثير ضار على التناسل فى الأناث. والجذور الحرة الناتجة عن الملوثات البيئية قد ينتج عنها مخاطر عالية التى تتسبب فى أنواع مختلفة من الأمراض التي تسبب تأخرًا في النمو. وبالتالي، فإن الحفاظ على التوازن بين مضادات الأكسدة والجذور الحرة أثناء الحمل أو فترة الرضاعة يلعب دورًا مهمًا في لأوزان الحى الأمهات. 